\title{
Concomitant Medication Previous Occurrence
}

National Cancer Institute

\section{Source}

National Cancer Institute. Concomitant Medication Previous Occurrence. NCI Thesaurus.

Code C83055.

An indication or description that a particular concomitant medication was taken in the past. 